\title{
ETHICS IN STEM CELL RESEARCH
}

\author{
Md. Fakruddin \\ Scientific Officer, Industrial Microbiology Laboratory, \\ Institute of Food Science and Technology (IFST), \\ Bangladesh Council of Scientific and Industrial Research (BCSIR), Dhaka. \\ Email: fakruddinmurad@gmail.com
}

\begin{abstract}
Stem cells have constituted a revolution in regenerative medicine and cancer therapies by providing the possibility of generating multiple therapeutically useful cell types that could be used for treating some of genetic and degenerative disorders. However, human embryonic stem cell research raises few ethical and political controversies because of its involvement in destruction of human embryos. The ethical issues in human embryonic stem cell research encompasses not only with question of the ethics of destroying human embryos, but also with questions about complicity of researchers in destruction of embryos, moral distinction between creating embryos for research purposes and creating them for reproductive ends and the permissibility of cloning human embryos to harvest stem cells. Bangladesh should formulate its own regulations justifying its stand regarding this matter.
\end{abstract}

Key words: Stem cells, Applications, Prospects, Ethics.

INTRODUCTION: Few technologies spark as much interest, hope and controversy as stem cell technology. Many people have strong opinions about the morality of stem cell research, but few have a strong understanding of the science and its potential. The excitement about stem cell research and its potential therapeutic applications is clearly evidenced by the large investments into research that have been made by corporations, governments and universities around the globe. Tempering the exuberance, however, are the myriad ethical, legal, and political challenges that face this field of research. The eventual resolution of these conflicts will determine the success of the research and potentially the face of medicine in the future ${ }^{1}$.

What is stem cell? Stem cells are unspecialized cells with remarkable potentiality to develop into many different cell types. They are capable of renewing themselves through cell division ${ }^{2}$. Under special condition they can be induced to become tissue or specific cell with defined function, these distinguishing features make stem cell different from other types of cell. Stem Cells are undifferentiated cells that through replication have the capability of both self-renewal and differentiation into mature specialized cells $^{3,4}$.

Properties of stem cell: Stem cells have some unique properties compared to normal cells. First, they have longevity. They divide and replicate under laboratory conditions for long periods of time without differentiating until induced to do so. Second, they have plasticity. They are able to differentiate into different types of specialized cells, such as cardiac muscle or pancreatic cells ${ }^{5,6}$.

History of stem cell research: Since their discovery in the early 1900 s, stem cells have captured the imagination of scientists. Interest intensified, however in 1998, when Professor James Thomson at the University of Wisconsin isolated and grew stem cells derived from human embryos ${ }^{7}$. Soon thereafter, researcher from Johns Hopkins University achieved similar results with human germ stem cells ${ }^{8}$. These advances impelled a wave of stem cell research around the world, focusing on three areas: human development, birth defects and therapeutics. 
ETHICAL ISSUE OF STEM CELL RESEARCH: Ethical challenges are not new to medicine and medical research. Stem cell research raises the concern that humans are "playing god". This concern is particularly relevant when discussing the cloning of human embryos for research purposes. There is also the possibility of inadvertent germ-line (reproductive cells) manipulation, even with the use of adult stem cells. Germ-line manipulation would result in the genetic modification of the offspring and would have a permanent impact on the human species ${ }^{9,10}$.

As therapies are developed and commercialized, society will have to consider the ethical implications of not only science but also the management of the corporations that bring such treatments to market ${ }^{11,12}$.

The source of tissues used to obtain stem cells in one of the most incendiary topics surrounding stem cell research. The president's council of Bioethics suggested three primary and recurring points of contention with regard to the issue of tissue sources: the moral status of human embryos, complicity and the "alternative of adult stem cells"13,14.

Stem cell research is controversial not because of its goals, but rather because of the means of obtaining some of the cells. The crux of the debate centers around embryonic stem cells, which enable research that may facilitate the development of medical treatments and cures, but which require the destruction of an embryo to derive. In addition, because cloning is one method of producing embryos for research, the ethical issues surrounding cloning are also relevant ${ }^{15,16}$.

Table-I. Ethical issues at different phases of stem cell research ${ }^{17}$

\begin{tabular}{|l|l|}
\hline Phase of research & Ethical issues \\
\hline Donation of biological materials & Informed and voluntary consent \\
\hline Research with hESCs & Destruction of embryos Creation of embryos specifically \\
& for research purposes \\
& 1. Payment to oocyte donors \\
& $\begin{array}{l}\text { 2. Medical risks of oocyte retrieval } \\
\text { 3. Protecting reproductive interests of women in } \\
\text { infertility treatment }\end{array}$ \\
\hline $\begin{array}{l}\text { Use of stem cell lines derived at another } \\
\text { institution }\end{array}$ & Conflicting legal and ethical standards \\
\hline Stem cell clinical trials & $\begin{array}{l}\text { Risks and benefits of experimental intervention } \\
\text { Informed consent }\end{array}$ \\
\hline
\end{tabular}

A discussion of ethics in stem cell research cannot however be limited to the research arena. As therapies will be developed and commercialized, society will have to consider the ethical implications of not only the science but also the management of the corporations that brings such treatments to market ${ }^{18,19}$. Several of these issues are discussed in more detail in the following.

Tissue source: The source of tissue used to obtain stem cells is one the most incendiary topics surrounding stem cell research. Three primary and recurring points of contention with regard to the issue of tissue sources are- the moral status of human embryos, complicity and the "alternative of adult stem cells" ${ }^{13,20}$.

Moral status refers to the inherent worth of something from a moral standpoint (rather than economic, technical or other standpoint) ${ }^{21}$. The key question is, when does an embryo become a human? Some argues that to destroy a fetus in the course of research is simply to take the life of an innocent human 
individual. This unambiguous assertion holds that all embryonic stem cell research is morally wrong, regardless of potential benefit ${ }^{22}$. Some other argues that becoming human requires more than the potential to develop into a human child. Following this logic, it is morally acceptable to destroy surplus or cloned embryos for the greater benefit of society ${ }^{23}$. Complicity relates to the question of who is responsible for embryo destruction. The third point of contention is "the alternative of adult stem cells". Some contend that therapies derived from adult stem cells are not sufficient to advance research and innovations $\mathrm{s}^{24,25}$. Hence research using stem cells from all sources including embryo should go forward.

Legal issues: A report issued by the $\mathrm{NIH}$ in 2000 stated that "congressional prohibition does not prohibit the funding of research utilizing human pluripotent stem cells because they are not embryos" ${ }^{\prime 26}$. However, the report also stated that appropriations law (P.L. 105-277, section 511,112 STAT, 2681-386) prohibits funds "for the creation of a human embryo or embryos for research purposes, or research in which human embryos are destroyed, discarded or knowingly subjected to risk of injury or death"27,28. The problem, of course, is that human embryonic stem cells are derived from early embryos. The proposed NIH answer is to permit funding for pluripotent stem cell research while denying funding for deriving stem cells from embryos $^{29,30}$. According to them, fund can be used "only if the cells were derived from early human embryos that were created for the purposes of infertility treatment and were in excess of clinical need of the individuals seeking such treatment" ${ }^{\prime 11,32}$.

Worldwide Regulation Scenario: Policies on stem cell research vary greatly from nation to nation. Britain is leading the drive for acceptance of stem cell research. In early 2001, the U.K. parliament approved the amendment of the 1990 Human Fertilization and Embryology Act governing research on human embryos, which allows the use of embryos up to fourteen days old for research on the derivation and potential of human stem cells. In Israel, a national bioethics committee in 2001 approved the derivation of embryonic stem cells and research into therapeutic cloning. The bioethics committees of Australia, Canada and Japan have also allowed stem cell research. In Germany, parliament voted in January 2002 to allow research on imported human embryonic stem cell lines that had been created before January 20,2002 . These cell lines can only be used for research projects approved by regulatory body. But, in China, research on embryonic tissue is generally banned, according to the Chinese Health Ministry. However, the study of stem cells drawn from the umbilical cord and afterbirth is permitted ${ }^{33-35}$.

Bangladesh Scenario: No such research using stem cells have been known to be performed in Bangladesh so far, though in-vitro fertilization and storage of germ cells is not new here. Government and policy makers still are not aware of this matter, hence no government regulation and policy on the acceptability and use of stem cell in research is yet to be formulated. Strict but rational regulations should be prepared and be in place for prospective stem cell research in this country to preserve ethical and moral values of the country people and to prevent unethical, unauthorized and unscientific use of stem cells in future. A national Bioethics committee should be formed to guide the government in this issue. Bangladesh being a Muslim country, it will be difficult to gain acceptability of this type of research from common people. Considering all the facts, government should make its stand clear with appropriate logic in this ground. Today or tomorrow, the wave of stem cell research will reach Bangladesh due to its immense commercial potential. So, we should be prepared well ahead of the time.

CONCLUSION: Stem cell research has the potential to lead to the development of novel cellular and gene therapies that could be translated into effective and safe clinical treatments of numerous genetic and degenerative disorders in humans. Although stem cells are highly unlikely to contribute to human fantasies of immortality and eternal youth, tremendous progress has been made in the past few years in the potential use of these cells as therapeutic agents, which may lead to prolonged life with less suffering and higher quality. In order to safely use stem cells or their differentiated progeny, methods of purification 
and methods of cell-death control will need to be developed. Another important aspect of stem-cell-based therapies will be the necessity of preventing the rejection of the donated cells by the immune system. In summary, much basic research lies ahead before application of a stem cell therapy to patients in a rigorous therapeutic manner is realized. However, mankind will surely benefit enormously by conducting research in this important area.

\section{REFERENCES:}

1. Mezey E, Key S, Vogelsans G, Szalayoua I, Lange GD, Crain B. Transplanted bone marrow generates new neurons in human brains. Proc Natl Acad Sci USA 2003; 100(3): 1364-9.

2. Barry FP, Murphy JM. Mesenchymal stem cells: clinical applications and biological characterization. Int J Biochem Cell Biol 2004; 36(4): 568-84.

3. Burt RK, Loh Y, Pearce W, Beohar N, Barr WG, Craig R, et al. Clinical Applications of blood-derived and marrow-derived stem cells for nonmalignant diseases. JAMA 2008; 299(8): 925-36.

4. Pera MF, Trounson AO. Human embryonic stem cells: prospects for development. Development 2004; 131(22): 5515-25.

5. Chapman AR, Frankel MS, Garfinkel MS. Stem cell research and applications monitoring the frontiers of biomedical research. American Association for the Advancement of Science and Institute for Civil Society. 1999.

6. Bobis S, Jarocha D, Majka M. Mesenchymal stem cells: characteristics and clinical applications. Folia Histochem Cytobiol 2006; 44(4): 215-30.

7. Thomson JA, Itskovitz-Eldor J, Shapiro SS, Waknitz MA, Swiergiel JJ, Marshall VS, et al. Embryonic stem cell lines derived from human blastocytes. Science 1998; 282(5391): 1145-7.

8. Gearhart J. New potential for human embryonic stem cells. Science 1998; 282(5391): 1061-2.

9. Bobrow JC. The ethics and politics of stem cell research. Trans Am Ophthalmol Soc 2005; 103: 13842.

10. Lo B, Parham L. Ethical issues in stem cell research. Endocrine Reviews 2009; 30(3): 204-13.

11. MacDonald C. Stem cell ethics and the forgotten corporate context. Am J Bioeth 2002; 2(1): 54-6.

12. Robertson JA. Ethics and policy in embryonic stem cell research. Kennedy Inst Ethics J 1999; 9(2): 109-36.

13. Outka G. The ethics of stem cell research. Meeting of the President's Council on Bioethics, April, 2002. Available at http://www.bioethics.gov/topics/stemcells_index.html. (Accessed on January 22, 2011).

14. Lodi $D$, lannitti $T$, Palmieri B. Stem cells in clinical practice: applications and warnings. J Exp Clin Cancer Res 2011; 30(1): 9. 
15. Williams ED, Johnson JA. Stem cell research: ethical issues. CRS Report for Congress. Congressional Research Service. 2008.

16. Davila JC, Cezar GG, Thiede M, Strom S, Miki T, Trosko J. Use and application of stem cells in toxicology. Toxicol Sci 2004; 79(2): $214-23$.

17. Pellegrini G, Luca MD, Arsenijevic Y. Towards therapeutic application of ocular stem cells. Semin Cell Dev Biol 2007; 18(6): 805-18.

18. Wobus AM, Boheler KR. Embryonic stem cells: prospects for developmental biology and cell therapy. Phys Rev 2005; 85(2): 635-78.

19. Dor Y, Brown J, Martinez OI, Melton DA. Adult pancreatic $\beta$-cells are formed by self-duplication rather than stem cell differentiation. Nature 2004; 429: 41-6.

20. Lennard AL, Jackson GH. Stem cell transplantation. BMJ 2000; 321: 433-7.

21. Brock DW. Bioethics: Messing with Mother Nature, Review of Our Posthuman Future, by Francis Fukuyama. American Scientist Online, September. 2002. Available at http://www.americanscientist.org (Accessed on January 23, 2012).

22. Ivanovic Z. Hematopoietic stem cells in research and clinical applications: the "CD34 issue". World J Stem Cells 2010; 2(2): 18-23.

23. Farley M. Roman catholic views on research involving human embryonic stem cells. [Conference abstract]. Presented at the $42^{\text {nd }}$ National Bioethics Advisory Commission Meeting. Bethesda, MD, USA. July, 2000.

24. Ramón-Cueto A, Cordero MI, Santos-Benito FF, Avila J. Functional recovery of paraplegic rats and motor axon regeneration in their spinal cords by olfactory ensheathing glia. Neuron 2000; 25(2): 425-35.

25. Liras A. Future research and therapeutic applications of human stem cells: general, regulatory, and bioethical aspects. J Transl Med 2010; 8(1): 131.

26. National Institutes of Health. Guidelines for Research Involving Human Pluripotent Stem Cells. 2001. Available at http://www.hhs.gov/news/press/2001 pres/01fsstemcell.html (Accessed on January 25, 2012).

27. Mimeault M, Hauke R, Batra SK. Stem cells: a revolution in therapeutics - recent advances in stem cell biology and their therapeutic applications in regenerative medicine and cancer therapies. Clin Pharmacol Ther 2007; 82(3): 252-64.

28. Krause K, Schneider C, Jaquet K, Kuck KH. Potential and clinical utility of stem cells in cardiovascular disease. Stem Cells and Cloning: Advances and Applications 2010; 2010(3): 49-56.

29. Bjorklund LM, Sánchez-Pernaute R, Chung S, Andersson T, Chen IY, McNaught KS, et al. Embryonic stem cells develop into functional dopaminergic neurons after transplantation in a parkinson rat model. Proc Natl Acad Sci USA 2002; 99(4): 2344-9. 
30. Zoloth L. Stem cell research: a target article collection: part I- Jordan's banks, a view from the first years of human embryonic stem cell research. Am J Bioeth 2002; 2(1): 3-11, 30.

31. Kimbrel EA, Lu SJ. Potential clinical applications for human pluripotent stem cell-derived blood components. Stem Cells Int 2011; 2011: 273076

32. Hughes SM. Muscle development: reversal of the differentiated state. Curr Biol 2001; 11(6): 237-9.

33. Tonti GA, Mannello F. From bone marrow to therapeutic applications: different behaviour and genetic/epigenetic stability during mesenchymal stem cell expansion in autologous and foetal bovine sera? Int J Dev Biol 2008; 52(8): 1023-32.

34. Velasco I, Mayani H. Stem cells: basic aspects and possible therapeutic applications. In: ChimalMonroy J. ed. Topics in Animal and Plant Development: From Cell Differentiation to Morphogenesis. Kerala: Transworld Research Network; 2011. p.163-80.

35. Power C, Rasko JE. Promises and challenges of stem cell research for regenerative medicine. Ann Intern Med 2011; 155(10): 706-13. 